\title{
Research on University Students' Ideological and Political Education in the New Era
}

\author{
He Zhang, Chen Yuan \\ Heilongjiang Bayi Agricultural University, Daqing, China \\ Email: 954661833@qq.com
}

How to cite this paper: Zhang, H., \& Yuan, C. (2020). Research on University Students' Ideological and Political Education in the New Era. Open Journal of Social Sciences, $8,217-221$.

https://doi.org/10.4236/jss.2020.86018

Received: April 9, 2020

Accepted: June 12, 2020

Published: June 15, 2020

Copyright (C) 2020 by author(s) and Scientific Research Publishing Inc. This work is licensed under the Creative Commons Attribution International License (CC BY 4.0).

http://creativecommons.org/licenses/by/4.0/

(c) (i) Open Access

\begin{abstract}
In the new era, ideological and political education for college students in China has become particularly important and crucial. From macro and micro perspectives, ideological and political education has its certain necessity and severity. In the meantime, as the times have changed, China's social environment has also undergone major changes, and it has also had many effects on the progress of ideological and political education, such as changes in the recipients of education, unsatisfactory results after education, and so on. Therefore, under this situation, all colleges or universities in our country should make every effort to adapt to the changes of the times, enhance the way of ideological and political education, and propel the education method to cater for social changes, so as to make the ideological and political education of college students better. This paper aims to uncover the current situation of ideological and political education of college students in the new era through literature and interview methods, and then discovers and analyzes some problems in ideological and political education, and finally proposes corresponding solutions to the problems.
\end{abstract}

\section{Keywords}

Undergraduates, Ideological, Political, Education

\section{Introduction}

Strengthening ideological and political education has always been the prerequisite and guarantee for the revitalization of education in China. How to strengthen the ideological and political education of contemporary college students in the context of socialism with Chinese characteristics is a long process of inheritance, development and innovation. Ideological and political education is the soul of all the work and research of colleges and universities. Colleges or universities 
must adhere to the principle of combining ideological and political education theory and practice, and then develop and innovate it for adapting to the development of socialist education, so as to comprehensively promote the development of various colleges or universities, update the concept of talent, and innovate educational mode to build the cultural spirit of higher vocational education. Therefore, it is necessary to conduct relevant research on the political education of college students in the new era. Based on the above background, this article will conduct an in-depth study of college students' ideological and political education.

\section{The Status of University Students' Ideology in the New Era}

From the perspective of value, the self-protection awareness of college students is gradually increasing, focusing on the realization of self-value. For example, college students pursue their own value interests in the society, tend to design themselves, and achieve their goals through their own values. At the same time, college students' thoughts and consciousness are gradually formed in the pursuit of self-value, but there are many confusions in the pursuit of self-value, and they pay more attention to personal development and prefer utilitarianism. There are also some students who are lazy in their daily life, have no sense of labor, without hard-working spirit, frugal, etc. From this part, it can be seen that this type of college students lack the awareness of independent labor. When students are looking for work after graduation, they always choose one out of the other, and want to find high-paying, relatively easy jobs, which will make it difficult for college students to find employment in the long run. Therefore, it is particularly important for college students to cultivate good ideology and political awareness during college. Through the construction of ideology and morality, the physical and mental qualities of students can be improved. Colleges and universities should regard the ideological and moral construction of college students as an important core so that students can develop good ideology and morality, diligence, modesty, and independent working consciousness. After college students leave campus and enter the society, the whole society should also actively take measures to cultivate and build the ideology and morality of college students, such as strengthening network resource management and prohibiting the flow of bad moral information. We need to carry out legal public activities and regularly hold publicity ideas in the community and flexible moral construction activities enable college students to gain a deeper understanding of knowledge, advocate the mainstream of culture by purifying the social environment, make students stay in a good environment, avoid the interference of other external bad information, and then make social environment more suitable for college students through the society and the college continuous efforts to improve the ideology and morality of college students.

\section{Problems in Ideological and Political Education of University Students in the New Era}

1) The political thought of university students is not mature enough 
(Wang, 2016) pointed out some issues in his book "Discussion on Problems and Countermeasures in Contemporary College Students' Ideological and Political Education". With the continuous development of society, social environment has become more and more complex. College students' ability to judge right and wrong is weak due to lack of rich social experience, which affects their ideological and political cognition and understanding in complex social environments. Some students are immature in their ideology and political thought, thus students cannot restrain themselves well. For example, during school, some students regard the school rules and regulations as unpredictable and unimportant, some bad behaviors can occur in the public arena. These series of actions have seriously affected the lives and learning environment of college students. Nowadays, due to the immature ideology and politics of college students, the educational work toward students cannot be carried out well, which further affects the growth and life of students.

2) The methods of ideological and political education are inadequate

Under the circumstance of the new era, all colleges and universities have also recognized the importance of ideological and political education, which should be strengthened. However, there are many unsatisfactory ways to strengthen between colleges and universities. At present, many colleges and universities still remain at the superficial level of cognition for ideological and political education. Teachers lack novel teaching methods in ideological and political education, and the content of the classroom is relatively boring, making it difficult to raise students' interest. Ideological and political classes are in conflict, which ultimately leads to a decline in the effectiveness of education.

(Li, 2014), in his book named "Research on the Existing Problems and Countermeasures in the Ideological and Political Education of Contemporary College Students", believes that in the classroom, in the classroom, teachers pay more attention to theoretical knowledge for ideological and political education, and regard teaching as a stressful task, which cannot put the theories into reality. Therefore, the value of ideological and political education is not shown entirely.

3) University students lack correct understanding of ideology and political thoughts

(Lin, 2016) argued in "Effective Strategies for Ideological and Political Education in Colleges and Universities under the New Media Environment" this book, the key content of ideological education in colleges and universities is Marxism. However, through the whole education, it is found that college students have a superficial understanding of Marxist theory, and cannot understand it in depth. College students attach great importance to the study of professional courses, and ignore the ideological and political courses. When conducting ideological and political lessons, most students are less interested in learning, and even in ideological and political lessons, some students tend to play mobile phones, sleep, and read other books.

It can also be found from some investigations, which can reflect the education of ideology and politics is very severe, and it is very necessary to cultivate politi- 
cal literacy for college students. When entering the university, many students want to join the Communist Party, but the idea of joining the party is different. Some students think that joining the party is a proud thing, and other students want to join the party in order to obtain more benefits. This also shows that their ideological and political thought doesn't enhance a high level. After joining the party, some students lacked senses of responsibility and did not play the role of party members in schools and society.

\section{Strategies for Optimizing the Ideological and Political Education of College Students in the New Era}

1) The education of ideals and beliefs of college students should be strengthened

Nowadays, confronting with the complex environment of society, the growth and life of students are also affected variably. From the past to the present, the spiritual pillars of mankind are faith and ideals, so do college students. For the ideological and political education of college students in the new era, we must first cultivate their ideals and beliefs, improve students' sense of social responsibility and mission. While students are in school, colleges and universities should carry out diverse activities to stimulate the ideals and beliefs of college students, such as studying traditional Chinese culture and conducting corresponding elective courses. Through a variety of learning methods, we enhance the ideological beliefs of college students, and thus also enhance their overall quality.

2) The methods of ideological and political education should be innovated

Ideological education is inseparable from teacher's education. But today's teaching methods do not satisfy students' deep learning of ideological and political education, which even has the opposite effect, resulting in poor educational results. In the process of ideological and political education, teachers should integrate political conditions with social development and use political education as a platform to improve the ideological and political level of college students. At the same time, society and families should also create a good learning atmosphere so that college students can get a more effective ideological education.

3) Students' political ideology should be strengthened

Under the current situation, college students should raise their ideological and political awareness quickly and establish correct concerns. Chinese universities should also pay more attention to ideological and political education. College students are actively encouraged to conduct ideological and political learning, and relevant educational institutions should be established in schools, and the efficiency of ideological and political education in colleges and universities should be improved through the establishment of institutions. Some corrections should be made to the deficiencies in ideological and political education. In addition, we should take ideological and political education as a key educational project. Correct ideological and political concepts are constantly instilled in college students in classrooms, so that they can establish correct ideological concepts. 


\section{Conclusion}

In summary, undergraduates in the new era are the future and hope of our country. Only by continuously strengthening and advancing the ideological and political education of undergraduates, they will be able to guide their growth. The ideological education of college students is also a long educational process, which needs the continuous efforts and help from society, schools and families to constantly strengthen the political thought of college students. In addition, a professional and high-quality ideological and political education team should be forged, whose function is to optimize education and teach methods. We should combine with traditional Chinese culture and education, so as to deepen the political thinking of college students, and cultivate excellent high-quality talents for the country.

\section{Conflicts of Interest}

The authors declare no conflicts of interest regarding the publication of this paper.

\section{References}

Li, H. L., \& Huang, J. (2014). Research on the Problems and Countermeasures in the Ideological and Political Education of Contemporary College Students. Knowledge Economy.

Lin, H. Y. (2016). Effective Strategies for Ideological and Political Education in Colleges and Universities under the New Media Environment. Asia Pacific Education.

Wang, Y. (2016). Discuss the Problems and Countermeasures in the Ideological and Political Education of Contemporary College Students. China Market. 